$$
\begin{array}{r}
\text { Pontifícia Universidade Católica } \\
\text { do Rio de Janeiro }
\end{array}
$$

\title{
ASPECTOS TEÓRICOS DA NARRATIVA CONTEMPORÂNEA EM ROMANCES DE PHILIP K. DICK
}

\author{
Tese de Doutorado
}

Tese apresentada ao Programa de Pós-graduação em Letras do Departamento de Letras da PUC-Rio como parte dos requisitos parciais para obtenção do título de Doutor em Letras.

Orientadora: Profa. Heidrun Friedel Krieger Olinto de Oliveira

Rio de Janeiro

Abril de 2008 


\section{Pontifícia Universidade Católica \\ DO RIO DE JANEIRO

\section{Anderson Soares Gomes}

\section{ASPECTOS TEÓRICOS DA NARRATIVA CONTEMPORÂNEA EM ROMANCES DE PHILIP K. DICK}

Tese apresentada como requisito parcial para obtenção do grau de Doutor pelo programa de Pós-Graduação em Letras do Departamento de Letras do Centro de Teologia e Ciências Humanas da PUC-Rio. Aprovada pela Comissão Examinadora abaixo assinada.

\footnotetext{
Profa. Heidrun Friedel Krieger Olinto de Oliveira Orientadora Departamento de Letras - PUC-Rio
}

Profa. Daniela Gianna Claudia Beccaccia Versiani Departamento de Letras - PUC-Rio

Profa. Pina Maria Arnoldi Coco Departamento de Letras- PUC-Rio

Prof. Valéria da Silva Medeiros

UFTO

Profa. Ana Lúcia de Souza Henriques

UERJ

Prof. Luiz Fernando Medeiros de Carvalho

UFF

Prof. Paulo Fernando Carneiro de Andrade Coordenador Setorial do Centro de Teologia e Ciências Humanas - PUC-Rio

Rio de Janeiro, de de 
Todos os direitos reservados. É proibida a reprodução total ou parcial do trabalho sem autorização do autor, da orientadora e da universidade.

\section{Anderson Soares Gomes}

Graduou em Letras, na especialidade Inglês-Literaturas, pela Universidade Estadual do Rio de Janeiro (UERJ) em 2002. Em 2005, também pela UERJ, recebeu o grau de Mestre em Letras na área de Literaturas de Língua Inglesa

Ficha Catalográfica

Gomes, Anderson Soares

Aspectos teóricos da narrativa contemporânea em romances de Philip K. Dick / Anderson Soares Gomes ; orientadora: Heidrun Friedel Krieger Olinto de Oliveira. 2008.

154 f. ; $30 \mathrm{~cm}$

Tese (Doutorado em Letras) - Pontifícia Universidade Católica do Rio de Janeiro, Rio de Janeiro, 2008.

Inclui bibliografia

1. Letras - Teses. 2. Historiografia literária. 3. Narrativa contemporânea. 4. Philip K. Dick. I. Heidrun Friedel Krieger Olinto de Oliveira. II. Pontifícia Universidade Católica do Rio de Janeiro. Departamento de Letras. III. Título.

CDD: 800 


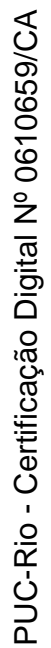

Para aqueles capazes de ver além da própria realidade. 


\section{Agradecimentos}

A Célia e Evelyn, pela paciência e compreensão.

A Bruno, pela bondade.

A Deus, pela inspiração.

A Amaury e Gleiciele, pelo incentivo.

Aos mestres pela ajuda incalculável: Ana Lucia Henriques, Marília Rothier, Valéria Medeiros.

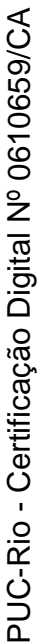

A Heidrun e Daniela - pelo apoio, encorajamento, idéias e pelo meu despertar mais que epistemológico. 


\section{Resumo}

Gomes, Anderson Soares; Olinto de Oliveira, Heidrun Friedel Krieger (Orientadora). Aspectos teóricos da narrativa contemporânea em romances de Philip K. Dick. Rio de Janeiro, 2008. 154p. Tese de Doutorado - Departamento de Letras, Pontifícia Universidade Católica do Rio de Janeiro.

Esta tese investiga a configuração verbal, as estruturas narrativas e os tópicos temáticos recorrentes em alguns romances do autor norte-americano Philip K. Dick - The Man in the High Castle, Time Out of Joint e Do Androids Dream of Electric Sheep? - à luz de teorias literárias contemporâneas. É dada ênfase especial à problematização da subjetividade na elaboração do texto histórico a partir de uma abordagem construtivista dos processos de percepção da realidade. A escolha da obra de Dick se justifica pela crescente importância do escritor para os estudos não só da ficção científica, mas também para a investigação de técnicas narrativas específicas presentes tanto no discurso historiográfico quanto no discurso literário pós-moderno. Nessa perspectiva, a obra de Philip K. Dick ilustra múltiplos aspectos da sociedade contemporânea, dando-se destaque, entre outros, à objetificação da experiência humana e à ‘musealização’ do presente.

\section{Palavras-chave}

Historiografia literária, narrativa contemporânea, Philip K. Dick. 


\section{Abstract}

Gomes, Anderson Soares; Olinto de Oliveira, Heidrun Friedel Krieger (Advisor). Theoretical aspects of contemporary narrative in novels by Philip K. Dick. Rio de Janeiro, 2008. 154p. PhD Thesis - Departamento de Letras, Pontifícia Universidade Católica do Rio de Janeiro.

This thesis investigates the verbal configuration, the narrative structures and recurrent themes in some novels written by American author Philip K. Dick The Man in the High Castle, Time Out of Joint and Do Androids Dream of Electric Sheep? - in the light of contemporary narrative theory. Emphasis is given to the analysis of the subjectivity present in the historical text and to the constructivist approach concerning the perception of reality. Dick’s work was chosen due to the growing importance of this author not only for the study of science fiction, but also for the investigation of narrative techniques present in the historiographic discourse and in the postmodern literary discourse. In this perspective, Philip Dick's work illustrates different aspects of contemporary society, such as the objectification of human experience and the 'musealization' of the present.

\section{Keywords}

Literary historiography, contemporary narrative, Philip K. Dick. 


\section{Sumário}

Introdução

1. A Ficção Científica no Século XX e Narrativas de Reconstrução da Realidade

1.1. Transmutações na Ficção Científica

1.2. Teorias Contemporânea da Narrativa

1.3. Philip K. Dick e a Ênfase na Construção da História

2. “Insira a Moeda na Porta” - Philip K. Dick e a Crítica à Sociedade do Consumo

2.1. Pós-Modernismo e o Castelo Alto do Espetáculo

2.2. Objetificação e Personificação

3. "Essa Maldita Historicidade Não Tem Sentido" - Historiografia e Narratividade

3.1. Um Passado, Diferentes Narrativas

3.2. Tempos Imemoriais

4. Conclusão: Realidades Oscilantes 


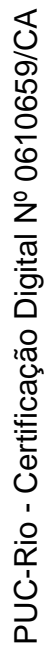

Realidade, para mim, não é algo que se percebe, mas algo que se cria.

Philip K. Dick 